\title{
ЦИФРОВІ РИЗИКИ В УМОВАХ ДИСТАНЦІЙНОЇ ОСВІТИ В ЧАСИ ПАНДЕМІЇ
}

Наукова доповідь на методологічному семінарі НАПН України

"Актуальні проблеми психологічної протидії негативним інформаційним

впливам на особистість в умовах сучасних викликів» 8 квітня 2021 р.

https://doi.org/10.37472/2707-305X-2021-3-1-13-3

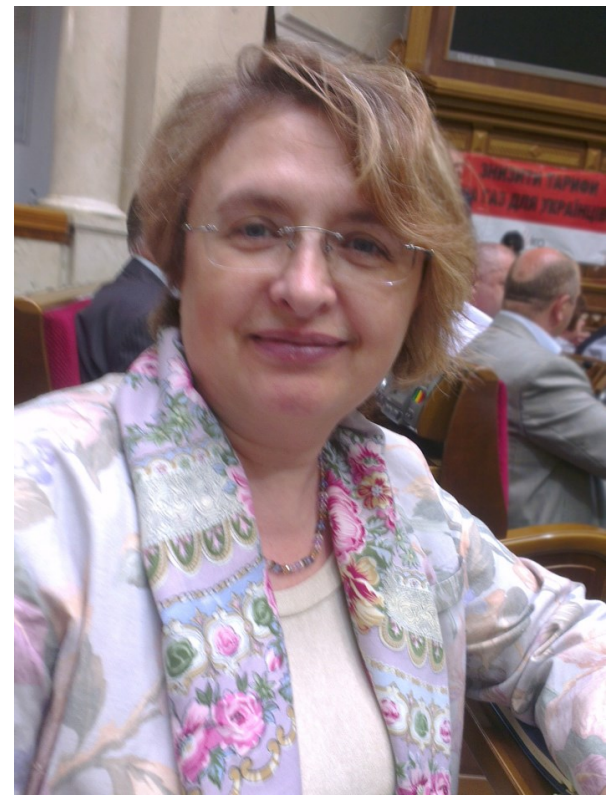

НАЙДЬОНОВА

Любов Антонівна

доктор психологічних наук, профресор, член-кореспондент НАПН України, заступник директора з наукової роботи Інституту сочіальної ma політичної психології Національної академії педагогічних наук України, м. Київ, Україна

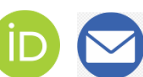

Анотація. Протягом пандемічного 2020 року відбулися зміни в медіапрактиках учнів порівняно з 2018 роком. Результати всеукраїнського дослідження онлайн-ризиків очима підлітків, проведеного лабораторією психології масової комунікації та медіаосвіти Інституту соціальної та політичної психології Начіональної академії педагогічних наук України, висвітлюють загальні тендениії зростання кіберризиків і визначають, на чому освітянам та батькам варто сконцентрувати спільні зусилля.

Ключові слова: інтернет-ризики; дистанційна освіта; медіаосвіта; булінг; пандемія.

Глобальний виклик пандемії COVID-19, оголошеної Всесвітньою організацією охорони здоров'я у березні 2020 р., вимушено зсунув усі людські практики в цифровий простір через необхідність дотримання карантинних обмежень і загострив проблему інформаційно-психологічної безпеки дітей у цифровому просторі. Інтернет, ставши провідним каналом доступу до зовнішнього світу в умовах депривації інших способів комунікації, змінив картину ризиків, з якими стикаються підлітки в кіберпросторі. Частина цих цифрових ризиків є досить прогнозованою, але частина лишається майже зовсім не обговорюваною з дорослими, прихованою. Як виглядають цифрові ризики та їхня динаміка протягом пандемічного періоду очима дітей - залишається мало дослідженим, принаймні на рівні створення картини цієї реальності в масштабах усієї країни.

Дослідження проблеми становлення особистості в умовах взаємодії з медіапростором активно і концентровано вивчаються вченими створеної з цією метою 2006 р. лабораторії психології масової комунікації та медіаосвіти Інституту соціальної та політичної психології Національної академії педагогічних наук України. За майже 15 років діяльності лабораторії питання інформаційної безпеки, досліджень психологічних наслідків деструктивних інформаційних впливів, умови кіберсоціалізації дитини постійно знаходилися в фокусі уваги. Так, з 2008 р. досліджується рівень медіакультури учнівської молоді, який включає індикатори психологічного благополуччя і медіаризиків, що дає змогу проаналізувати динаміку інформаційного простору та його рівень небезпечності для дітей. Наукові розробки систематично представляються широкому колу освітян на всеукраїнських і міжнародних масових заходах, зокрема освітянських виставках і в педагогічній пресі. 
Mema здійсненого дослідження - висвітлення безпеки підлітків в Інтернеті протягом 2020 р.: зміни традиційних ризиків і появи нових шкідливих впливів під час пандемії для учнів 7-10 класів порівняно з рівнем, зафіксованим 2018 р. Завдання роботи - виявити загальні тенденції щодо кібербулінгу в умовах карантину та з'ясувати динаміку інших цифрових ризиків. Аналіз даних дослідження обґрунтовує актуальність напрямів профілактичної роботи для освітян і батьків.

Всеукраїнське опитування проводилось у межах діагностично-розвивального проєкту «Медіакультура в умовах пандемії» відповідно до програми експерименту з упровадження медіаосвіти, затвердженої наказом МОН України від 18 серпня 2017 р. № 1199, та ії̈ доповнення планом заходів із протидії пандемії, затвердженим Президією НАПН України.

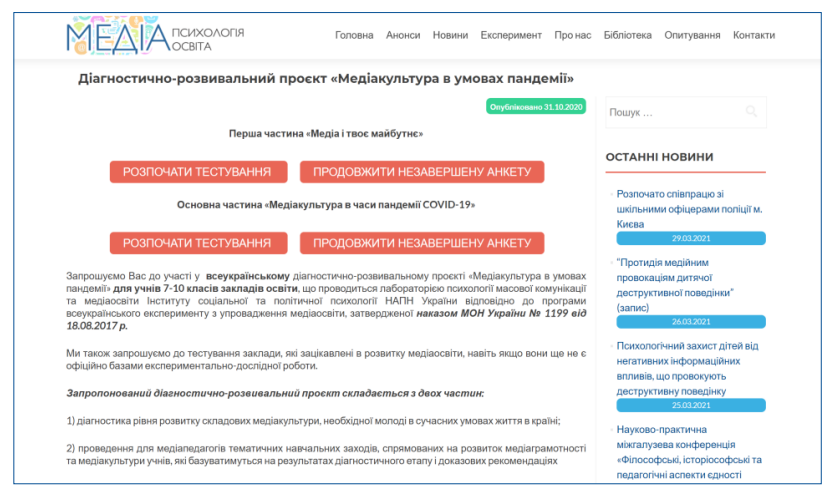

Опитування проводили дистанційно у листопаді-грудні 2020 р. на базі 75 шкіл з більшості областей. Охоплено понад 3 тис. учнів 7-10 класів, які взяли участь у різних блоках опитувань. Вибірку становили 1732 особи, які взяли участь у семи запропонованих блоках опитувань діагностично-розвивального проєкту.

3 нових небезпек інформаційного впливу пандемія насамперед актуалізувала загрозу здоров'ю: 33 \% підлітків повідомили, що відчували страх заразитися. Про страх за близьких більший, ніж за себе, звітувала понад половина (53 \%). Серед опитуваних було 18 \%, які вказали, що перехворіли або хворіють на момент опитування. Решта знаходилась або на самоізоляції, або під впливом того, що знайомі або друзі хворіють. Напружені переживання підлітків було великою мірою зініційовано впливом медіапростору з постійною інформацією про статистику захворюваності, смертності, небезпеки ускладнень для старших людей.

Інфодемія (від «інформація» і «епідемія») другий напрям нових ризиків, що створюється через перенасичення інфопростору повідомленнями про пандемію, зокрема недостовірною і токсичною інформацією. 38 \% підлітків відзначають, що їм було важко розібратись, де правда про COVID-19. Загалом близько $60 \%$ підлітків стверджували, що вчителі чи дорослі розказували їм, що робити та як захиститись від COVID-19. Проте велика частка підлітків (20\%) зазначила, що їм ні з ким було поговорити про це. Так, кожен п'ятий підліток потрапляє до групи підвищеного ризику, оскільки дорослим не відомо, в якому стані перебувають такі діти, оскільки їхня потреба спілкуватися ігнорується найближчим оточенням.

Зважаючи на домінування у інфопросторі візуальної інформації, окремо розглянуто ризик негативного впливу різних зображень коронавірусу. Найбільш розповсюдженому традиційному зображенню 20 \% учнів дали максимальну оцінку за параметром «це зображення лякає», тобто візуальний ряд оформлення медійних повідомлень додатково може підсилювати в дітей відчуття страху в умовах загрози захворіти.

Пандемія вплинула й на динаміку традиційних інтернет-ризиків, до яких насамперед відносимо кібербулінг (з його восьма основними видами), який загалом зріс приблизно удвічі за період 3 кінця 2018 р. до кінця 2020 р. Є види, які зростають більше, деякі - менш інтенсивно.

За даними 2018 р., коли не було пандемії, майже кожен п'ятий підліток стикався з: нападками, тролінгом, погрозами (1); наклепом (2). Кожен шостий 3: перепалками (3); переслідуванням (4); самозванством і фішингом (створення фальшивих ідентичностей) (5); ошуканством, шахрайством (6); ізоляцією (бойкотом) (7); хепіслепінгом (відеозйомка інших для розваги) (8). Жодний із цих видів кібербулінгу не охоплював третину підлітків.

У сучасних умовах бачимо, що майже третина підлітків стикається 3: нападками, тролінгом, погрозами (1); перепалками (3); ізоляцією (7). А з рештою зазначеної вище вісімки - вже кожен п'ятий учень. Таке істотне зростання кардинально змінило характер традиційних кіберризиків.

Особливо небезпечні ризики, що створюють загрозу життю та здоров'ю дитини і до пандемії були досить рідкісними, але сьогодні суттєво зросли. На рис. 1 колами позначено ризики, що траплялися не часто - про них повідомляли до $5 \%$ дітей. На кожен клас хоча $б$ одна дитина могла бути під впливом цих кіберризиків. Нині бачимо, що саме ці надзвичайно шкідливі, 


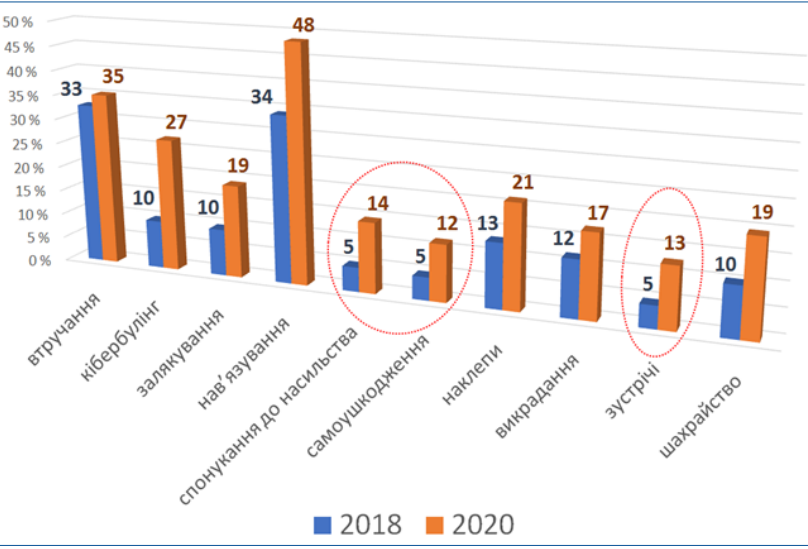

Рис. 1. Зростання інтернет-ризиків підлітків у 2020 р. порівняно з 2018 р.

рідкісні, злоякісні ризики фактично зростають, й дуже інтенсивно.

Спонукання до насильства (агресії та підбурювання нетерпимого ставлення до інших) зросло приблизно втричі (14\%). Підштовхування до самоушкодження (суїцидальні ігри) збільшились приблизно удвічі (12\%). Спілкування із незнайомими людьми з небажаними наслідками, наприклад, небезпечні зустрічі з ними в реальності також зросли більше ніж у два рази (13\%). Крім того, 2020 р. уперше перелік традиційних цифрових ризиків було розширено тими, що мають сексуальне забарвлення. Виявлено, що принаймні кожен шостий підліток перебуває під тиском потенційних злочинців-звабників. На відміну від погроз, які лишаються в кіберпросторі, переслідування може призвести до реальних ризикованих зустрічей.

Це дуже небезпечна тенденція, на яку обов'язково потрібно звернути увагу в роботі насамперед з батьками, які мають надавати дітям інструменти, як поводитись у критичних ситуаціях, а не просто інформувати про загрози. Будь-яка розповідь про загрози може спровокувати бажання повторити і зробити це. Негативна статистика призначена дорослим, аби зрозуміти, на що звернути увагу, які уміння розвивати у дітей для профілактики ризиків. Батьки часто думають, що діти в період карантинних обмежень знаходяться в безпеці вдома, але насправді вони перебувають у зоні значного зростання цифрових ризиків. Карантинні обмеження посилили соціальну ізоляцію, а це один із чинників погіршення психологічного добробуту.

Отже, порівняння результатів масових всеукраїнських опитувань підлітків, проведених 2018 і 2020 рр. свідчать про значне зростання майже усіх інтернет-ризиків за показником частки учнів
7-10 класів, які повідомляють про те, що стикалися в мережі саме з такими ситуаціями і діями інших проти себе. А група нових цифрових ризиків, пов'язаних із пандемією, є досить відчутною, охоплює значну частку опитаних підлітків, свідчить про погіршення загального емоційного фону в житті підлітків через нав' язування медіа почуття страху за себе і близьких, що посилюється непрогнозованими візуальними впливами, а також унаслідок інфодемії.

Перспектива подальших досліджень полягає у поглибленні аналізу зв'язків інтернет-вразливості підлітків із окремими формами дистанційної освіти, а також психологічними і психосоматичними наслідками тривалого стресу, що посилюється медіаповідомленнями. Окремо варто дослідити інформаційні впливи, які провокують деструктивну самоушкоджувальну поведінку та суїцидальні тенденції у підлітків, що поглиблює кризові стани в умовах соціальної ізоляції. На основі виявлених тенденцій мають бути розроблені зручні для використання розвивальнокорекційні модулі для здійснення інтегрованої медіаосвіти - фокусований на виявлених проблемах розвиток медіаграмотності педагогів, батьків і дітей. Потрібна також дискусія для широкої громадськості та медіаіндустрії.

\section{СПИСОК ВИКОРИСТАНИХ ДЖЕРЕЛ}

Інститут соціальної та політичної психології НАПН України. (n.d.). Головна. https://ispp.org.ua/

Лабораторія психології масової комунікації та медіаосвіти ІСПП НАПН України. (n.d.). Головна [Facebook Page]. Facebook. https://www.facebook.com/ medialabIISPP

Медіапсихологія і медіаосвіта. (2020). Діагностичнорозвивальний проєкт "Медіакультура в умовах пандемії». https://bit.ly/3t7ibpU

Міністерство освіти і науки України. (2017, 18 серпня). Про проведення всеукраїнського експерименту за темою "Стандартизація наскрізної соціальнопсихологічної моделі масового впровадження медіаосвіти у вітчизняну педагогічну практику» на базі навчальних закладів України (1199). https:// bit.ly/3mCfWso

Найдьонова, Л.А. (ред.), \& Дятел, Н.Д. (упоряд.). (2020). Кіберсоціалізація в умовах пандемії: матеріали IV науково-практичної семінару (5 листопада 2020 р., м. Київ,). https:// doi.org/10.33120/CSPProceeding-2020lssue1

Найдьонова, Л.А. (ред.), \& Кришовська, О.О. (упоряд.). (2018). Медіаграмотність та інформачійна безпека : інформаційний бюлетень. https:// bit.ly/2Q761yF

Найдьонова, Л.А. (2018). Кібербулінг у підлітковому рейтингу інтернет-небезпек. Психологічні науки: проблеми і здобутки, (1), 141-159. https:// bit.ly/3wol8Dn 


\section{DIGITAL RISKS DURING DISTANCE EDUCATION IN TIMES OF THE COVID-19 PANDEMIC}

Scientific report at the methodological seminar of the National Academy of Educational Sciences of Ukraine "Actual Problems of Psychological Resistance to Harmful Information Impact on Personality under Current Challenges" (April 8, 2021)

\section{Lyubov Naydonova}

DSc in Psychology, Professor, Corresponding Member of NAES of Ukraine, Deputy Director for Scientific Work, Institute for Social and Political Psychology of the National Academy of Educational Sciences of Ukraine, Kyiv, Ukraine

Abstract. There were changes in Internet safety during the pandemic 2020 year compared to 2018 data. The results of Ukrainian online research of cyber risks for school students, conducted by the Laboratory of Psychology of Mass Communication and Media Education at the Institute of Social and Political Psychology of the National Academy of Educational Sciences of Ukraine at the end of 2020 show general trend of cyber risks rising, and warn educators and parents for what risks they should be focused more attention for prevention.

Keywords: Internet risks; distance education; media education; bullying; COVID-19 pandemic.

Дата публікації: 10 квітня 2021 р. 